Research Article

\title{
Estimating Louisiana Crawfish Hatchery Production Function: An Application of Cobb-Douglas Production Function
}

\author{
Bukola B. Oluwade ${ }^{1}$ and Augustine Adu Frimpong ${ }^{2}$ \\ ${ }^{1}$ Southern University and A \& M College, Public Policy Department. Baton Rouge, Louisiana \\ ${ }^{2}$ Southern University and A \& M College, Public Policy Department. Baton Rouge, Louisiana and/or Valley \\ View University, Techiman Campus, Box 183, Brong- Ahafo Region, Ghana.
}

\begin{abstract}
It is an undeniable fact that the Louisiana Crawfish production over the years has been produced from wild habitats, mainly from the Atchafalaya River basin, which seems to be a factor of seasonality. Following the statistics of the total Crawfish production between 2004 and 2005 seasons, it was underscored that more than 82 million pounds of crawfishes were produced. Out of the 82 million capacity of crawfishes produced between 2004 and 2005, approximately $\mathbf{7 4}$ million pounds of Crawfishes were obtain from regular crawfish farms and more than 8 million pounds of crawfishes were harvested from natural habitats by the activities of approximately 1,100 fishermen. However, many of the crawfish farmers rely on natural reproduction system by unharnessed crawfish from the previous year or on mature crawfish that are stocked to produce young naturally. In addition, it is a fact that Crawfish aquaculture in the Louisiana State does not rely on hatchery system of operations. This has been a hindrance on the part of the crawfish farmers to stabilize the populating capacities of their ponds with crawfishes now (or currently) and in the near future. Therefore, this current study tends to model and investigate the Louisiana crawfish production with a control variable of hatching system by following the Cobb-Douglas production function/ theory. The study adopted a cross-sectional data collection procedure to sampled 320 crawfish farmers in the State of Louisiana with the help of Cluster random sampling technique. The study revealed that the engagement/involvement of crawfish farmers' in the hatchery system of production in the State of Louisiana are associated with the influence of labor cost and its availability; the cost of hatchery equipment; the size of the storage facility; initial estimation cost of capital; genetic effect of interbreeding; government regulation; and climatic conditions. The study recommended that the Louisiana State government and the other key stakeholders should do a frequent evaluation of the goals and performance of hatchery programs in a transparent manner to the benefit of the crawfish farmers, and also make available to the farmers with Federal and local government funds and expertise guidelines. Again, it was also recommended that policymakers should place a priority on research that will aid in developing solutions to potential problems and quantify factors affecting the relative reproductive success, and the longterm fitness of populations in order to influence the hatchery systems.
\end{abstract}

Key Words: Hatchery, Production, Natural and Wild-Habitats, Cobb-Douglas, Crawfish, Seafood, and Fishing

\subsection{Introduction:}

In fact, the Louisiana State is well-known in the production and consumption of seafood. Perceptibly, as long as a product comes from the water bodies and is edible, the state find a way to make it scrumptious and inimitable, an emblematic example is the Crawfish farming. To a large extent, Louisianans will not only eat the product but actually make it something others would have to travel to the state just to experiment it. Regarding this assertion, the people always package and brand their seafood products to be gorgeous and attractive for both the internal and external sphere of influence (demand).

Meanwhile, Crawfish as one of the innovative water-bodies products in the State of Louisiana has gone viral to the utility of both the internal and external sphere of influence. According to the National Geographic Survey (2014), Crawfish is referred to by several names including crawdads, crawfish, river crab, and mudbugs. In fact, Crawfish is very unique, which needs a maximum attention to serve as a revenue generator for both the citizens and the state. By its nature, it can be boiled, baked, or cooked into a delicious meal. In the state of Louisiana, Crawfish is one of the most versatile foods available and also gain a lot of popularity outside its territory. However, a lot of people still look down on this tiny crustacean and mull over it to be a less important dish than their saltwater cousins.
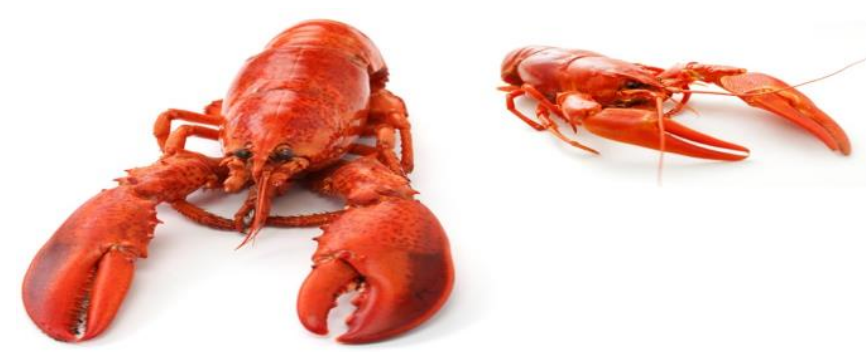


\section{Figure 1: A Picture of Fresh Water Crawfish}

Unlike, Lobsters which spend their lives in saltwater, including oceans and seas, crawfish set up shelter in fresh water, such as streams, rivers, and ponds. This implies that crawfish production can be expanded easily through artificial inventions. It is based on the assumption of expanding fish production through artificial inventions that the National Fish Hatchery System (NFHS) was established. This system is comprised of a network of field stations located throughout the nation that works with tribal, local, and state governments, other federal agencies, and foreign nations to conserve fisheries. Since the inception of the U.S. Fish and Wildlife Service in 1871, fisheries conservation has figured paramount to people and economies including crawfish as a product or an element of fisheries. Additionally, in 1965, the Fish \& Wildlife Service established seven Fish Technology Centers nationwide to provide science and technology support and guidance to the National Fish Hatchery System and fish culture community.

In the meantime, there are several factors which influence the production of fish (i.e. like crawfish) generally, which include water quality, type and quantity of vegetative forage, weather, lunar phase, and crawfish reproduction, growth and moulting patterns. Perhaps during the survey, it was perceived that the crawfish production industry in Louisiana is dominated by Crawfish ponds, which have no standard size, but most are between 10 and 40 acres, and most producers manage 150 or fewer acres over time (Louisiana Crawfish Production Manual).

In perusing several kinds of articles and publications, it was underscored that Louisiana's crawfish farming industry has grown to include more than 1,200 farms occupying more than 120,000 acres. Also, the production from wild habitats, mainly the Atchafalaya River basin, diverges from year to year. Again, the total production between 2004 and 2005 season was more than 82 million pounds, with almost 74 million pounds from farms and more than 8 million pounds harvested from natural habitats by approximately 1,100 fishermen (Louisiana Crawfish Production Manual). Statistically, in the final analysis, the crawfish industry in the State of Louisiana grosses more than $\$ 300$ million annually and employs over 7,000 people. Because of the statewide significance of the invention, Louisiana was the first state to name an Official Crustacean (The Crawfish) in 1983 (Louisiana Crawfish Promotion and Research Board; and Louisiana Crawfish Production Manual).

However, many crawfish farmers rely on reproduction by unharnessed crawfish from the previous year or on mature crawfish that are stocked to produce young naturally. In addition, Crawfish aquaculture in the Louisiana State does not rely on hatchery operations for populating ponds, and other freshwater bodies; rather, recruitment is solely achieved by means of natural reproduction. Nonetheless, the total reliance on natural reproduction is probably the foremost reason for production unevenness from year to year and pond to pond.
Thus, reproduction in crawfish continues to be a most important research prominence. Surprisingly, from the perspective of agricultural science, the production of crawfish feeds on rice, sorghum, and natural vegetation. These crops are grown in the summer period (i.e. when ponds are drained) to serve as the base of a natural food chain for crawfish (Louisiana Crawfish Production Manual). Despite, its enormous benefits the state tends to gain from this unique industry, less attention has been given to the production of crawfish. This current study tends to estimate the production function of crawfish in the state of Louisiana. The CobbDouglas production function will be followed and modified to suit the crawfish hatchery production function.

\subsection{Literature Review}

According to FAO Corporate Document Repository, in order to design a marine fish hatchery, the investor has to have a clear idea about its production target. A decision on the size of the hatchery is a fundamental pre-requisite before starting the search for suitable sites, or before starting the technical design or the financial plan.

A study conducted by K. M. Brander and W. Easterling (2007) on global fish production and climate change. A number of climate-related threats to both capture fisheries and aquaculture were identified, but they have low confidence in predictions of future fisheries production because of uncertainty over future global aquatic net primary production and the transfer of the fish production through the food chain to human consumption. In their recent study, they found out that changes in the distribution and productivity of a number of fish species can be ascribed with high confidence to regional climate variability, such as the El Niño-Southern Oscillation. They further theorize that future production may increase in some high-latitude regions because of warming and decreased ice cover, but the dynamics in low-latitude regions are governed by different processes, and production may decline as a result of the reduced vertical mixing of the water column and, hence, reduced recycling of nutrients. Furthermore, they found that there were strong interactions between the effects of fishing and the effects of climate because fishing reduces the age, size, and geographic diversity of populations and the biodiversity of marine ecosystems, making both more sensitive to additional stresses such as climate change. Finally, they concluded that inland fisheries are additionally threatened by changes in precipitation and water management. That is, the frequency and intensity of extreme climate events are likely to have a major impact on future fisheries production in both inland and marine systems.

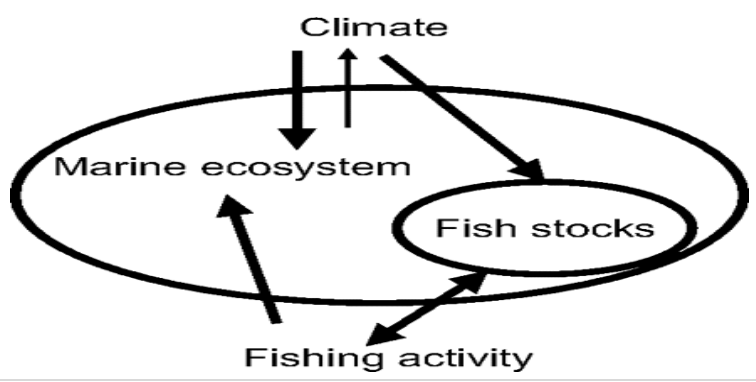


Brander, and Easterling (2007), Schematic representation of impacts of climate change and fishing activity on the marine ecosystem and its fish component

\subsection{History of Crawfish Production}

Following the Native Americans and the early European settlers, the crawfish has been an inherent part of Louisiana culture. Abundant in the swamps and marshes across south Louisiana, crawfish were a favourite food for early residents. As part of History, several centuries thereafter, crawfish season in Louisiana is still exciting, with crawfish boils and backyard parties a time-honoured tradition. It is very important to note that commercial sales of crawfish in Louisiana began in the late 1800 s. At that time, crawfish were harvested from natural waters throughout the southern region of the state. The first record of a commercial crawfish harvest in the United States was in 1880. That year, a harvest of 23,400 pounds was recorded, with a value of $\$ 2,140$. According to Louisiana Crawfish Promotion and Research Board, by 1908, a U.S. Census report listed Louisiana's crawfish production at 88,000 pounds, with a value of $\$ 3,600$.

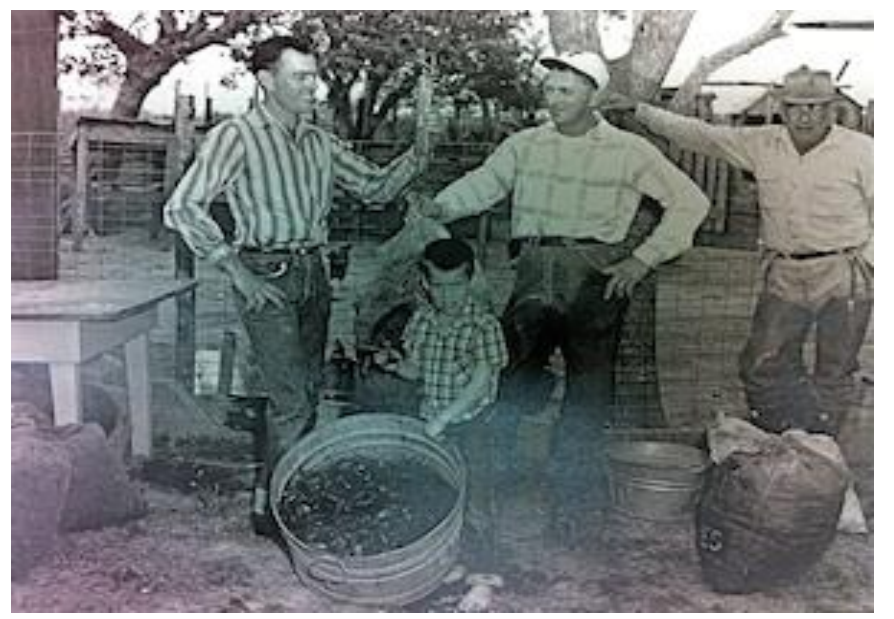

In fact, the Louisiana Crawfish Promotion and Research Board underscored that the technological advances have explained the growth of the Louisiana crawfish industry to include farming as well as fishing in the wild. In the 1960's, crawfish farming made its debut with the cultivation of crawfish in man-made ponds, using controlled water levels, forage management and water recalculation techniques to produce a highly marketable product.

According to Louisiana Crawfish Promotion and Research Board (LCPRB), during the next 35 years, crawfish farming developed into the largest freshwater crustacean aquaculture industry in the United States. Very importantly, it was underscored that Louisiana leads the nation, producing more than $90 \%$ of the domestic harvest. Below is the map showing the major cities, towns and neighbouring states in the United States of America, of Louisiana State:

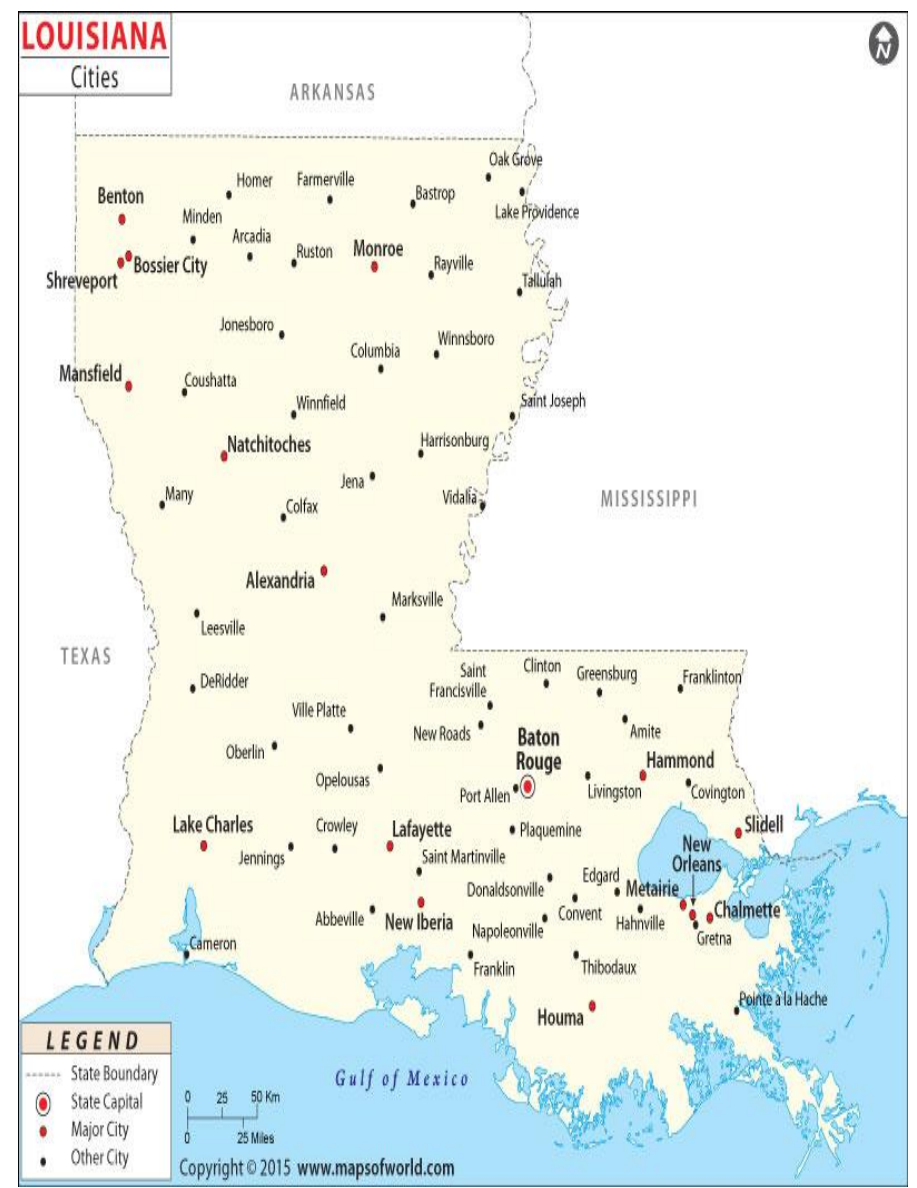

Source:htps://www.mapsofworld.com/usa/states/louisiana/ city-map.html

\subsection{Gallery of Hatchery Fishing Which Can Be Replicated in the Louisiana State of USA}

Since the 1940s, it was clear that artificial production of fish needed a better basis in fish science. The primary purposes of hatcheries continued to be the production of fish to compensate for habitat destruction and lost natural production, and also to produce large numbers of fish for commercial harvest.

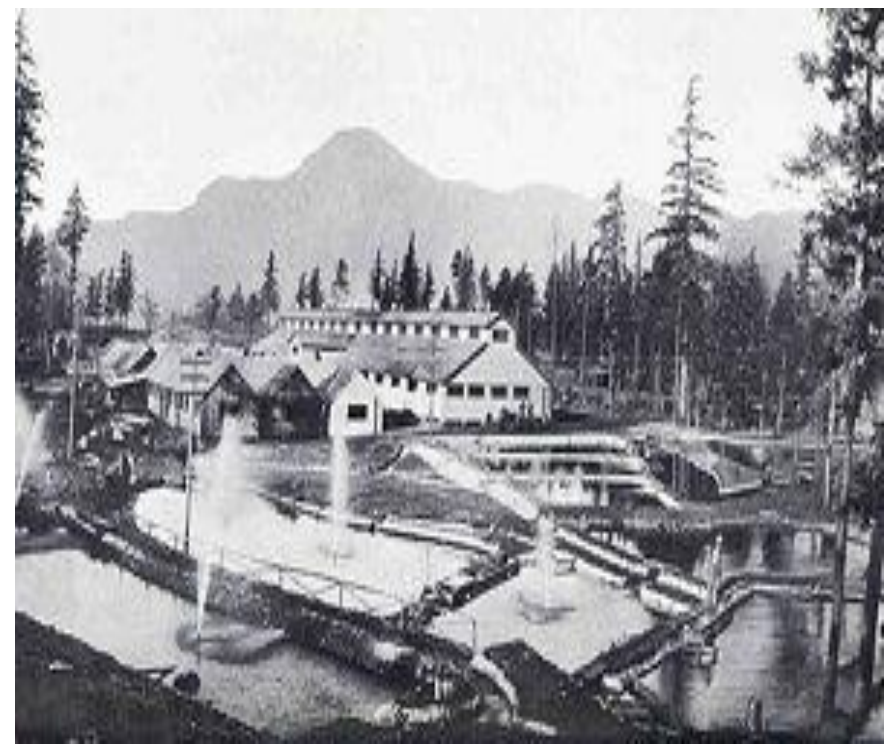

A picture of Bonneville Salmon Hatchery of the Oregon Fish and Game Commission, Showing Rearing Ponds 


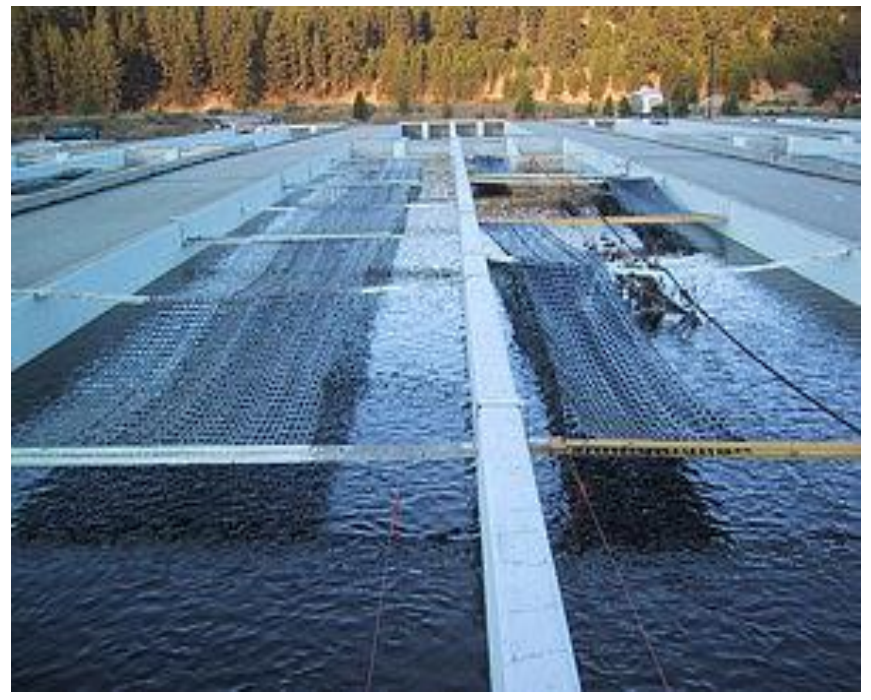

A picture showing "Natures" technique at Sawtooth hatchery where natural conditions are mimicked in raceways Photo: 2005 ISRP tour.

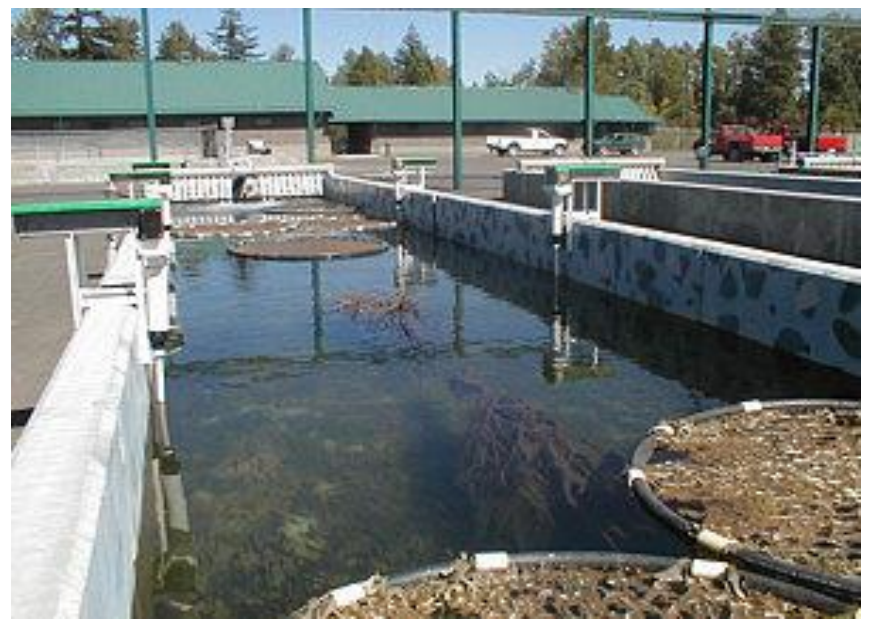

A picture showing "Natures" technique at Yakima hatchery where natural conditions are mimicked in raceways. Photo: 2005 ISRP tour.

\subsection{Method and materials}

This current study is steered by Mankiw et al. (1992), Knowles and Owen (1997) and Blom et al. (2004). These eminent authors' theorized that growth in output emerges from input combination and technology. In the present study, inputs are reproducible physical capital $(\mathrm{K})$ and labour $(\mathrm{L})$. The reproducible capital is assumed to be composed of hatchery system $(\mathrm{H})$, and technological progress (A). The hatchery system $(\mathrm{H})$ is decomposed into machinery preservation and regenerating more of the offspring (s) outside the natural source. Then the aggregate Cobb-Douglas production function is therefore transformed as given below:

$Y=A \mathbf{L}^{\alpha} \mathbf{K}^{\beta} e^{\varphi \mathbf{h}+\lambda s_{\theta} t}$

With this understanding, the hatchery production system (1) can be rewritten as:

$y=A \mathrm{~L}^{\alpha} e^{\varphi \mathrm{h}+\lambda s_{\theta} \mathrm{t}}$

Equation (2) shows the per capital/worker production function. Taking logs of equation (2) yields $\ln y=\ln A+\alpha \ln \mathbf{L}+\varphi h+\lambda s+\theta_{\mathrm{t}}$

As indicated earlier, " $\boldsymbol{A}$ ” is a measure of technological advancement in the economy, which explained output growth that is not accounted for by changes in physical capital and/or labour (i.e. cost and labour availability). This is usually referred to as the Solow residual, similar to Mankiw (1972) theoretical analysis of technology which evolves through the economy. Following the variables, the empirical crawfish hatchery production - growth model could be stated as:

$\ln y=\beta 0+\alpha \ln \mathbf{l}_{\mathrm{i}}+\varphi h_{\mathrm{i}}+\lambda s_{\mathrm{i}}+\beta_{1} \mathbf{G I}_{\mathrm{i}}+\beta_{2} \ln \mathbf{M}_{\mathrm{i}}+\beta_{3} \mathrm{G}_{\mathrm{i}}+\beta_{4} X_{\mathrm{i}}+\boldsymbol{\theta}_{\mathrm{t}}$

Where

$\mathbf{y}=$ hatchery production (i.e. farmers projection of mechanized production through hatchery system)

l=labor (i.e. cost and labour availability)

$\mathbf{h}=$ cost of hatchery equipment (i.e. farmers projection of hatchery pieces of equipment cost)

$\mathbf{s}=$ estimated size of storage facilities for the assumed newly hatched crawfish offspring

GI= Genetic Effect of Interbreeding (Dummy variable: If genetic effect of interbreeding affect the decision to go into hatchery system $\mathrm{Yes}=1$ and $\mathrm{No}=0$ )

$\mathbf{M}=$ initial start-up capital

$\mathbf{G}=$ government regulation (Dummy variable: If government regulations serve as a hindrance to hatchery system Yes=1 and $\mathrm{No}=0$ )

\section{$\mathbf{X}=$ weather conditions}

Also, the variable is as defined before and the parameters to the parameters to be estimated $\operatorname{are} \varphi, \lambda, 1,2,3,4$ and 0 is the constant term. The error term is captured by and is assumed to be normally distributed with zero mean and constant variance while $i$ represent crawfish farmers.

\subsection{Empirical Discussion of Results}

\section{1: Data Presentations}

Figure 1: Demography of Sample Locations

\section{LOUISIANA CRAWFISH SAMPLE DEMOGRAPHY}

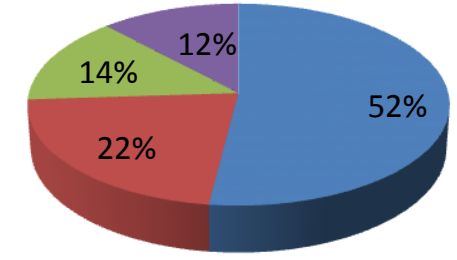

LAFAYETTE

- LAKE CHARLES

NEW ORLEANS

- BATON ROUGE 
Bukola B. Oluwade et al / Estimating Louisiana Crawfish Hatchery Production Function: An Application of CobbDouglas Production Function

Figure 2: Extent to which Storage Facility Influence the Hatchery Production

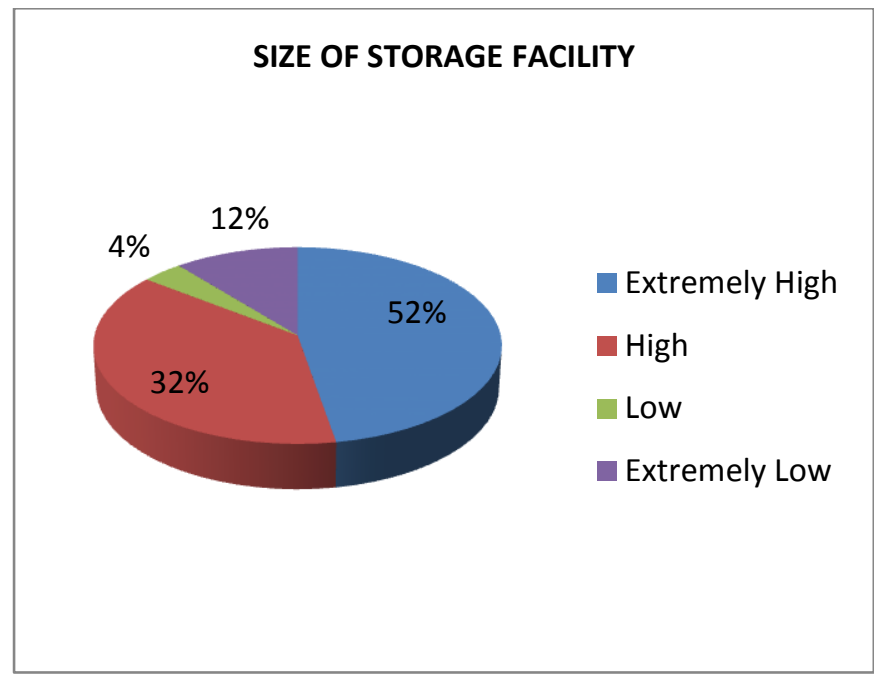

Source of Data: Field data, June 2017

Figure 3: Crawfish Farmers Willingness to Go into Hatchery Production

\section{CRAWFISH FARMERS WILLINGNESS TO ENTER INTO HATCHERY PRODUCTION}

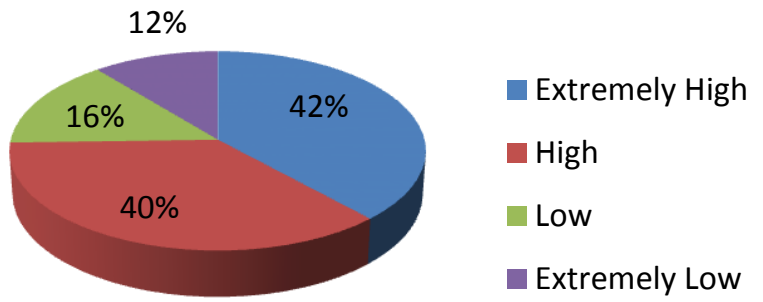

Source of Data: Field data, June 2017

Figure 4: Extent to which Initial Cost of Capital and Cost of Hatchery Equipment Influence the Hatchery Production

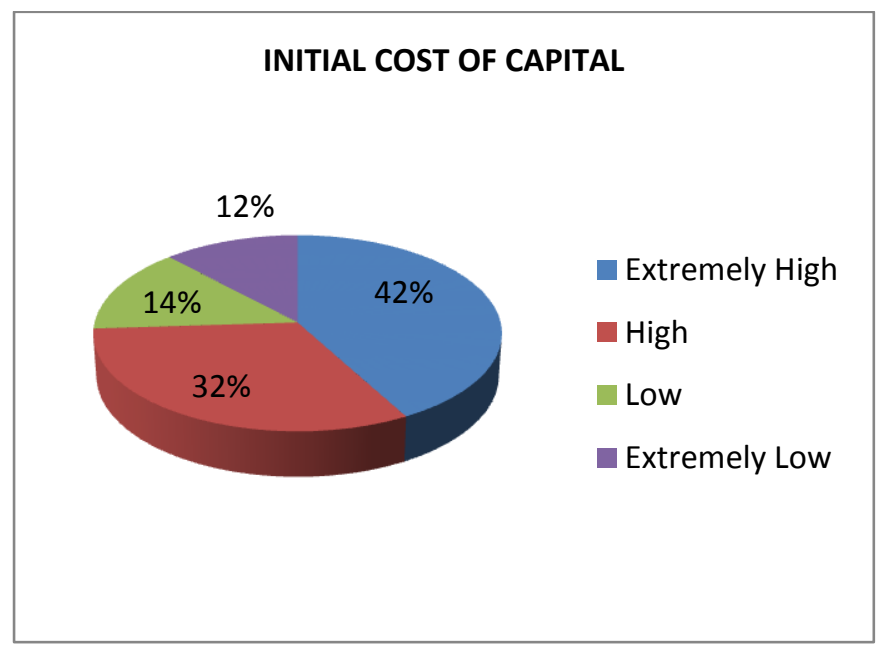

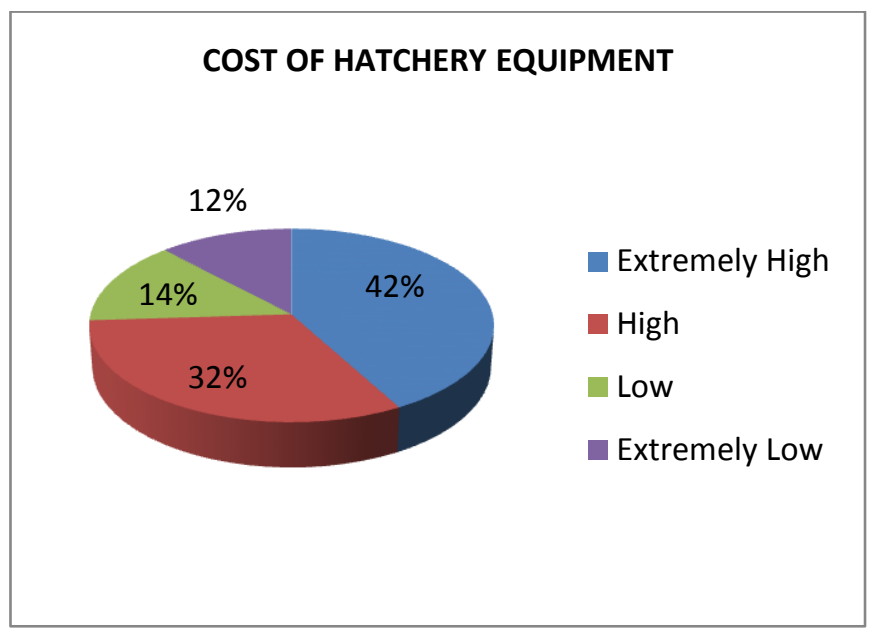

Source of Data: Field data, June 2017

Table 1: Regression Estimate of the Crawfish Hatchery Production Function

\begin{tabular}{llll}
\hline Variable & Coefficient & $\begin{array}{l}\text { Standard } \\
\text { Error }\end{array}$ & t-statistic \\
\hline $\begin{array}{l}\text { Labor (I) of } \\
\text { Cost }\end{array}$ & $0.0263 * * * *$ & .0226 & 3.8084 \\
$\begin{array}{l}\text { Hatchery } \\
\text { Equipment (h) }\end{array}$ & & & 7.0261 \\
$\begin{array}{l}\text { Size of Storage } \\
\text { Facility (s) }\end{array}$ & $0.3042 * * *$ & 0.0629 & 4.8381 \\
$\begin{array}{l}\text { Initial Capital } \\
\text { (M) }\end{array}$ & $1.7584 * * *$ & 0.5952 & 3.0794 \\
$\begin{array}{l}\text { Genetic Effect of } \\
\text { Interbreeding }\end{array}$ & $0.6483 *$ & 0.4851 & 1.0693 \\
(G) & & & \\
$\begin{array}{l}\text { Government } \\
\text { Regulation (G) }\end{array}$ & $0.1350 * * *$ & 0.0574 & 2.4764 \\
$\begin{array}{l}\text { Climatic } \\
\text { Conditions (X) }\end{array}$ & $0.0244 *$ & 0.0075 & 1.0043 \\
\hline $\begin{array}{l}\text { Intercept } \\
\text { R-Square }\end{array}$ & $1.9584 * * *$ & 0.5952 & 3.0895 \\
Sample (N) & & & 0.867 \\
\hline
\end{tabular}

Note: Standard errors are presented in parentheses. ***(**)* denotes significance at 1\%, 5\% and 10\% significance level respectively. Source of Data: Field data, June 2017

\section{2: Discussion}

Figure 1 shows the demographic sample of crawfish farmers in the State of Louisiana involved in the survey. In relation to the stratified field data, about $52 \%$ of the respondents were crawfish farmers sampled from the Lafayette community and surroundings, $22 \%$ of the respondents were crawfish farmers sampled from the Lake Charles community and surroundings, $14 \%$ of the respondents were crawfish farmers sampled from the New Orleans community and surroundings, and $12 \%$ of the respondents were crawfish farmers sampled from the Baton Rouge community and surroundings (i.e. including Port Allen). Indeed, crawfish production is seen more in Lafayette and Lake Charles communities and surroundings.

Figure 2 reveals the extent to which storage facility influence the Crawfish hatchery production in Louisiana. This survey is 
based on the farmers' perception. About $52 \%$ of the farmers from the various production units confirm that the influence of storage facility on the hatchery production is extremely high. In addition, about $32 \%$ of the farmers were of the view that the influence of storage facility on hatchery production is high. However, about $12 \%$ and $4 \%$ of farmers agree that the influence of storage facility is extremely low and low respectively.

Figure 3 discloses the extent to which crawfish farmers are willing to enter into hatchery production in Louisiana. Perceptibly, about $42 \%$ of the farmers were of the extremely high opinion that they will go into hatchery production in order to increase the stock of crawfish, all other things being equal. Additionally, $40 \%$ of the farmers highly agreed to the notion that they will go into hatchery production in order to increase the stock of crawfish, all other things being equal. However, about $28 \%$ of farmers were of the opinion that they are not ready to go into hatchery production due to several reasons. Among the many reasons include initial start-up capital, the cost of hatchery equipment, lack of government support (i.e. incentives), cost of the storage facility to keep the new young ones and the old ones.

Figure 4 make known the extent to which cost of initial capital and hatchery pieces of equipment influences the hatchery production in Louisiana. Perceptibly, about $42 \%$ of the farmers were of opinion that cost of initial capital and hatchery pieces of equipment influences hatchery extremely high. Additionally, $32 \%$ of the farmers were of opinion that cost of initial capital and hatchery equipment highly influences hatchery production. However, about $26 \%$ of farmers were of the opinion that the cost of initial capital and hatchery equipment has low influence on the hatchery.

The study by STATA 12 used p-values computed to determine the statistical significance of the variables estimated. The rejection of the null hypothesis was set at the $5 \%$, significance levels of the Two-tailed test, with a p-critical value of 0.05 . These results were obtained from STATA 12.

Table 1 summarizes the regression estimations of crawfish hatchery production in Louisiana. The coefficients of the independent variables (i.e. labor, cost of hatchery equipment, size of storage facility, initial capital, genetic effect of interbreeding, government regulation and climatic conditions) are the values with the asterisked and their probability effect of hatchery production engagement due to the various tested predictive variables is the sign the value possesses. All the regressors implications of hatchery production are statistically significant at $5 \%$ and $10 \%$ significance levels. This implies that crawfish farmers engagements in hatchery production in Louisiana are associated with the influence of labour cost and availability, the cost of hatchery equipment, the size of the storage facility, initial capital, genetic effect of interbreeding, government regulation and climatic conditions. Lastly, about $87 \%$ variation in the crawfish hatchery production systems is explained by the variations in labour, the cost of hatchery equipment, the size of the storage facility, initial capital, genetic effect of interbreeding, government regulation and climatic conditions.

\subsection{Conclusion and Policy Recommendation}

Based on the discussion of the field data, the study recommended the following:

It is highly recommended that the Louisiana government and other key stakeholders should do a frequent evaluation of goals and performance of hatchery programs in a transparent manner to the benefit of the crawfish farmers.

Also, the policymakers should place a priority on research that develops solutions to potential problems and quantifies factors affecting the relative reproductive success and long-term fitness of populations influenced by hatcheries.

Furthermore, the policymakers should design and operate hatcheries and hatchery programs with the flexibility to respond to changing conditions.

\section{References}

Brander K. M. and Easterling, W. (2007). Global fish production and climate change.

Pennsylvania State University, University Park, PA. vol. 104 no. 50 , 19709-19714, doi: 10.1073/pnas.0702059104.

Food Agriculture Organization (FAO) of the United Nations, Fisheries Department (2004) The State of World Fisheries and Aquaculture (FAO, Rome).

FAO Corporate Document: Title: Manual on hatchery production of seabass and gilthead seabream - Volume 2. (http://www.fao.org/docrep/008/y6018e/y6018e02.htm)

Knowles, S., and Owen, P. D.(1997). Education and Health in an Effective-Labour Empirical Growth Model, Economic Record, 1997, 73(223), pp. 314-28.

Louisiana Crawfish Production Manual: Louisiana State University Agricultural Center

(www.lsuagcenter.com)- LSU AgCenter Publication \# 2637

Louisiana Crawfish Promotion and Research Board. http://www.crawfish.org/history.html

Louisiana Crawfish Promotion and Research Board. http://www.crawfish.org/About.html

Mankiw, N. G., Romer, D., and Weil, D. (1992) A Contribution to the Empirics of Economic Growth, Quarterly Journal of Economics, 107(2), pp. 407-437 